\title{
The Effect of Aeroponic Potato Seeds from the Tropical Lowland and Highland Based on Size on the Growth and Yield to Become Advanced Seeds by Irrigation
}

\author{
Eni Sumarni ${ }^{1}$, Loekas Soesanto ${ }^{2}$, Noor Farid ${ }^{2}$, Ardiansyah ${ }^{1}$
}

10.18805/IJARe.A-514

\begin{abstract}
Background: Potato seed production with aeroponic technology can produce a large number of seeds, besides that it is also healthy because it uses plant seeds from tissue culture. However, how the quality of aeroponic seeds produced to become the next seed (growth capacity) has not been studied and scientifically informed. This research aimed to obtain the effect of aeroponic seed yields from the low and high plains based on their size on the growth and yield into advanced seeds. Potato seeds used were from the highland and lowland using aeroponic technology.

Methods: This research was conducted in the highland (1000 $\mathrm{m}$ above sea level) from April to July 2017. Seeds were classified as $\mathrm{S} \leq 1 \mathrm{mg}, 1 \leq \mathrm{Md} \leq 10 \mathrm{~g}$ and $\mathrm{L} \geq 10 \mathrm{~g}$. This research used a randomized block design with seven repetitions. The tried factors were as follows: 1 . The origin of aeroponic seeds $(A)$ : $A_{1}$ (lowland), $A_{2}$ (highland); 2 . The size of aeroponic seeds $(U): U_{1}(S), U_{2}(M), U_{3}(L)$. Plant growth parameters included plant height, number of leaves and number of tubers.

Result: The data obtained were analyzed using Duncan's multiple range test (DMRT) at the $5 \%$ level. Seeds of aeroponic yields of various sizes that are planted using drip irrigation have the potential to become advanced seeds. The L-size aeroponic seeds from the lowland produced an average of 5.9 tubers with an average weight of $68.4 \mathrm{~g}$.

Key words: Aeroponic, Greenhouse, Highland, Lowland, Potato seed, Seed size.
\end{abstract}

\section{INTRODUCTION}

Potatoes are tubers that are widely planted throughout the world; they have good nutrition and play a role in food security (Ahmadvand et al., 2009; Karim et al., 2010). According to FAO data (2007), the average production of potato plants in Australia reached 35.9 tons per hectare, while potato production in Indonesia is lower at 18 tons per hectare. The low productivity of potatoes is caused by the limited use of high-grade potato seeds among Indonesian farmers. Such seeds are relatively expensive and seed costs involve the largest proportion of total production costs (Karim et al., 2010). It is estimated that in developing countries, the cost of procuring potato seeds makes up 40 to $70 \%$ of the cost of crop production (Masarirambi et al., 2012).

Potato seed production in Indonesia is still low due to climate constraints, pests and plant diseases; it is also due to the limited number of potato seed breeders. Generally, the breeders still use the conventional cultivation method, potato plants face insect and potato cyst nematoda problems in their growing area as well as worldwide (Malik et al., 2018; Mhatre et al., 2019; Priyank et al., 2019). Good-quality potato seeds can be obtained quickly and the result is high enough using aeroponic cultivation. Production technology of aeroponic potato seeds has started to be studied and used by some seed breeders in Indonesia in order to increase the production of potato seeds. Commercial production of aeroponic potato seeds has been developed in Korea and China. In South America, this technology has been used
${ }^{1}$ Department of Agricultural Technology, Faculty of Agriculture, Jenderal Soedirman University, Purwokerto, Indonesia.

2Department of Agrotechnology, Faculty of Agriculture, Jenderal Soedirman University, Purwokerto, Indonesia.

Corresponding Author: Eni Sumarni, Department of Agricultural Technology, Faculty of Agriculture, Jenderal Soedirman University, Purwokerto, Indonesia. Email: arny0565@gmail.com

How to cite this article: Sumarni, E., Soesanto, L., Farid, N. and Ardiansyah (2021). The Effect of Aeroponic Potato Seeds from the Tropical Lowland and Highland Based on Size on the Growth and Yield to Become Advanced Seeds by Irrigation. Indian Journal of Agricultural Research. 55(6): 751-755. DOI: 10.18805/IJARe.A-514. Submitted: 09-12-2019 Accepted: 18-08-2021 Online: 06-09-2021

successfully since 2006 (Otazu, 2010). The aeroponic system in Peru's International Potato Center (CIP) produces more than 100 mini bulbs per plant. The production of aeroponic potato tubers reached 1340 bulbs from 100 plants/ $\mathrm{m}^{2}$ (Farran et al., 2006). In Indonesia, aeroponic technology has been developed. The result of financial analysis of the potato seed breeding business shows profitability with an $\mathrm{R} / \mathrm{C}$ ratio value of 2.38 , while the result obtained from the farmer breeder value is an $\mathrm{R} / \mathrm{C}$ ratio equal to 2.08 (Tedy et al., 2011). Aeroponic technology in Indonesia is also being studied for application in lowlands with root zone cooling (Sumarni, 2013; Sumarni et al., 2013a, b, c; Sumarni et.al., 2019). This technology is able to produce tubers of up to 14 tuber crops (Sumarni et al., 2013b). The production of 
The Effect of Aeroponic Potato Seeds from the Tropical Lowland and Highland Based on Size on the Growth and Yield to...

aeroponic potato seeds producing $30-40$ bulbs per plant in tropical highland (Sumarni et al., 2011). A potato seed tuber produced from aeroponic technology is a mini seed because it is grown inside a greenhouse and the root hangs in the air. Aeroponic potato seed production is profitable enough and produces a healthy seed because it comes from early seeds of tissue culture. However, how the quality of aeroponic seed to be the next seed (growing power) has not been further studied and informed scientifically.

Potato seeds are important in potato production (Rana et al., 2013). Poor potato seeds can reduce yields by $20 \%$ (Bentley and Vasques, 1998). The area of potato planting in the highland in Indonesia contains mostly endemic viruses and potato pests. Therefore, if the aeroponic potato seeds from the lowland and highland can produce advanced seeds, they can help the government reach self-sufficiency for seeds. This research aimed to obtain the effect of aeroponic seed yields from the lowland and highland based on their size on the growth and yield into advanced seeds.

\section{MATERIALS AND METHODS}

This research was conducted in the highland $(1000 \mathrm{~m}$ above sea level) from April to July 2017. The potato seeds used were derived from the highland and lowland with aeroponic technology. Seeds were classified into sizes $S, M$ and L. Size $S$ were aeroponic seeds with a size of $\leq 1 \mathrm{mg}$, size $M: 1 \leq M \leq 10 \mathrm{~g}$ and size $\mathrm{L} \geq 10 \mathrm{~g}$. The seeds used passed dormancy three months after harvest. The potato seeds were planted in a greenhouse with drip irrigation.

\section{Drip irrigation}

Drip irrigation system consist of pumps, main pipes, manipol pipes, lateral pipes and emitters, as well as other components such as valves, pressure gauges, filters (sand filter, disk filter and screen filter), faucets (ballvalve) and a nutrient solution tank. The distribution of nutrient solution with drip irrigation (drip system) is an open system; in other words, the nutrient solution that is streamed to the plant is not re-circulated. The pump is the driving force in the drip irrigation system to drain nutrients from the reservoir bucket to the plants. From the results of measurements that have been carried out, the average discharge using a pump is $1.85 \mathrm{~L} /$ hour. The uniformity of dropper discharge for irrigation with a pump was obtained a value of $79 \%$. The drip irrigation scheme is presented in Fig 1.

\section{Experimental design and analytical data}

The planting of aeroponic potato seeds with drip irrigation in this research used a randomized block design (RBD) with seven repetitions. The drip irrigation used consisted of seven lateral pipes. The distance between plants was $20 \mathrm{~cm} \times 20$ $\mathrm{cm}$. The size of the poly bag used was $35 \mathrm{~cm} \times 35 \mathrm{~cm}$ in diameter. Each lateral pipe contained 18 plants, so the number of plants was 126 in total. The tried factors were as follows: 1) The origin of aeroponic seed (A): A1 (lowland), A2 (highland), 2) The size of aeroponic seed (U): U1 (S), U2 (M), U3 (L).

The potato seeds planted with drip irrigation were given nutrients with a $\mathrm{pH}$ range of 6-6.5. Electric conductivity $(\mathrm{EC})$ at $1-1.5 \mathrm{mS} / \mathrm{cm}$ was provided at the beginning of planting to 30 days after planting (HST) and at $1.5-2 \mathrm{mS} / \mathrm{cm}$ for plants aged $>30 \mathrm{HST}$ to harvest ( $90 \mathrm{HST}$ ). Plant growth parameters included plant height, number of leaves and number of tubers. The data obtained were analyzed using Duncant's multiple drop test (DMRT) at the $5 \%$ level.

\section{RESULTS AND DISCUSSION \\ Air temperature around greenhouse for planting aeroponic potato seeds}

The air temperature around the planting location has an important effect on the growth and development of potato crops. The maximum air temperature in the planting greenhouse of potato seeds ranged from $24^{\circ} \mathrm{C}$ to a minimum of $10^{\circ} \mathrm{C}$. The maximum air temperature outside the greenhouse ranged from $23^{\circ} \mathrm{C}$ to a minimum of $8^{\circ} \mathrm{C}$ (Fig 2). This air temperature provided an optimal condition for the growth and development of potato crops. High air temperatures $\left(25-32^{\circ} \mathrm{C}\right)$ have a negative impact on the potato crop. Such temperatures can cause physiological defects in potato plants (Rykaczewska, 2013). Based on the results

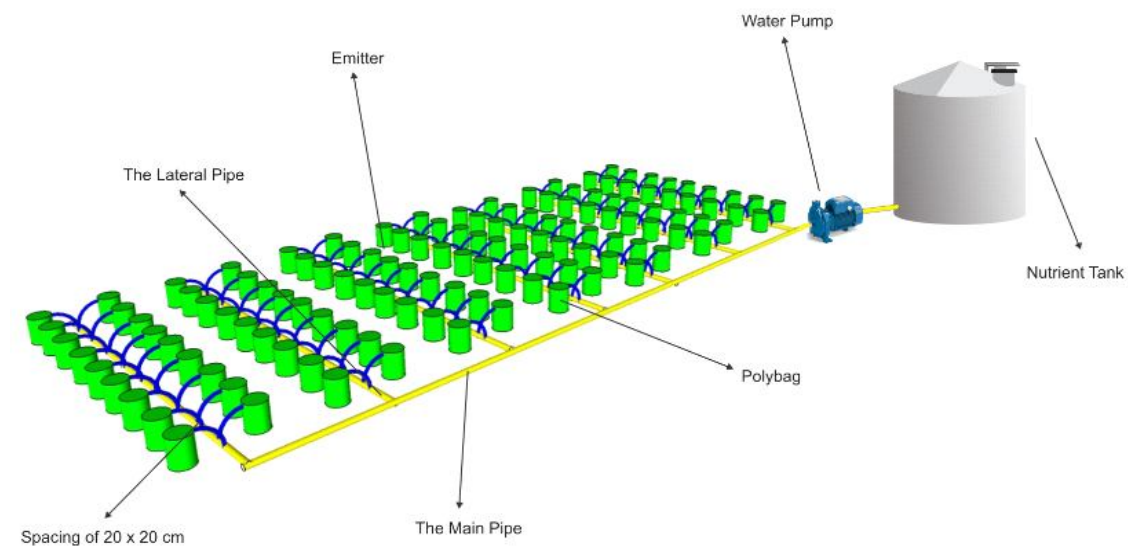

Fig 1: Drip irrigation application in this research. 


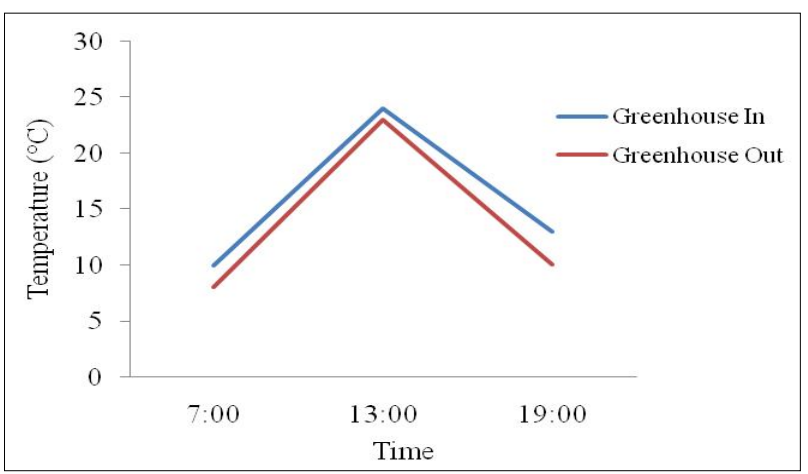

Fig 2: Air temperature inside and outside of the greenhouse.

of this research, the growth of potato plants occurs quickly at a temperature of $20-25^{\circ} \mathrm{C}$, while tuberization and optimal tuber development occur at a temperature of $15-20^{\circ} \mathrm{C}$ (Rykaczewska, 1993; Van Dam et al., 1996).

\section{Size of potato seeds for plant height growth}

The size of the aeroponic seeds planted using drip irrigation has a different effect on the plant height and number of leaves. The highest average of potato plants at the age of 10 to 50 days after planting (DAP) is achieved in the size of L-seed potatoes $(51.24 \mathrm{~cm})$ and in M-sized seeds at 50 days $(46.96 \mathrm{~cm})$. The height of potato plants aged 10 to 30 days at the $M$ size seed was the same as $S$. On the other hand the $M(46.96 \mathrm{~cm})$ size was higher than the size of $S$ $(37.45 \mathrm{~cm})$ seed at the age of 40 to 50 days after planting (Table 1).

The use of the $L$ potato seed size produced a higher number of leaves than the $M$ and $S$ sizes, except at the plant age of 40 and $50 \mathrm{HST}$, which did not differ in the number of leaves between tuber sizes L (94.52 leaves) and M (77.45 leaves) (Table 2).

The size of the aeroponic potato seeds regarding the advanced seed yield

The number of tubers produced showed that the potato seeds from the lowland produce the largest number of tubers

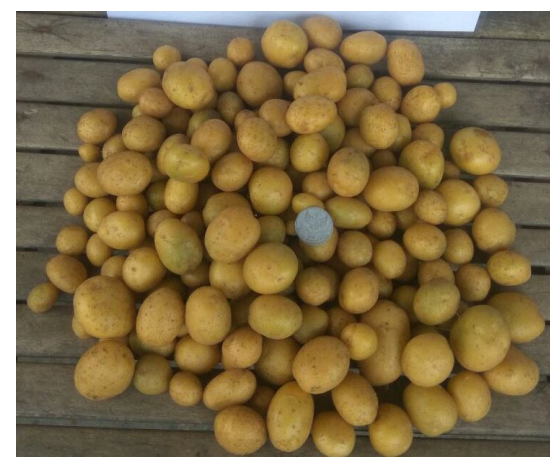

Fig 3: Advanced seeds produced.

compared to tuber seeds from highland aeroponic yields. The weight per tuber of the yield of potato seed production in lowland was heavier than the seed from the highland (Fig 4 and 5). The largest number of tubers was produced by aeroponic potato seeds from the lowland, with L-size (5.89 tubers) seed equal to the $S$ size (4.86 tubers). Production of potato tuber seeds in the lowland with $L$ size $(68.36 \mathrm{~g})$ results in the heaviest weight per tuber than the other sizes. The weight result per tuber for tuber seed production in the lowland for the M-size yield produce the same size as $\mathbf{S}$ and is heavier than tuber seed production in the highland for all seed sizes (L, M and S).

Table 1 : Differences in the use of potato seed size on plant height aged 10 to 50 days

\begin{tabular}{lccccc}
\hline \multirow{2}{*}{ Treatment } & \multicolumn{5}{c}{ Plant height $(\mathrm{cm})$} \\
\cline { 2 - 6 } & 10 DAP & 20 DAP & 30 DAP & 40 DAP & 50 DAP \\
\hline $\mathrm{L}$ & $23.90 \mathrm{a}$ & $27.48 \mathrm{a}$ & $34.48 \mathrm{a}$ & $44.83 \mathrm{a}$ & $51.24 \mathrm{a}$ \\
$\mathrm{M}$ & $16.71 \mathrm{~b}$ & $20.03 \mathrm{~b}$ & $24.72 \mathrm{~b}$ & $37.96 \mathrm{~b}$ & $46.96 \mathrm{a}$ \\
$\mathrm{S}$ & $14.51 \mathrm{~b}$ & $16.07 \mathrm{~b}$ & $20.86 \mathrm{~b}$ & $31.27 \mathrm{c}$ & $37.45 \mathrm{~b}$ \\
\hline
\end{tabular}

The numbers in the same column followed by the same letters are no different in the DMRT test level of $5 \%$.

Table 2: Differences in the use of potato seed size on the number of leaves aged 10 to 50 days.

\begin{tabular}{lccccc}
\hline \multirow{2}{*}{ Treatment } & \multicolumn{5}{c}{ Number of leaves } \\
\cline { 2 - 6 } & $10 \mathrm{DAP}$ & 20 DAP & 30 DAP & 40 DAP & 50 DAP \\
\hline $\mathrm{L}$ & $68.81 \mathrm{a}$ & $77.81 \mathrm{a}$ & $82.81 \mathrm{a}$ & $86.26 \mathrm{a}$ & $94.52 \mathrm{a}$ \\
$\mathrm{M}$ & $50.43 \mathrm{~b}$ & $56.45 \mathrm{~b}$ & $59.45 \mathrm{~b}$ & $72.45 \mathrm{a}$ & $77.45 \mathrm{a}$ \\
$\mathrm{S}$ & $47.36 \mathrm{~b}$ & $49.48 \mathrm{~b}$ & $54.15 \mathrm{~b}$ & $66.69 \mathrm{~b}$ & $71.69 \mathrm{~b}$ \\
\hline
\end{tabular}

The numbers in the same column followed by the same letters are no different in the DMRT test level of $5 \%$. 


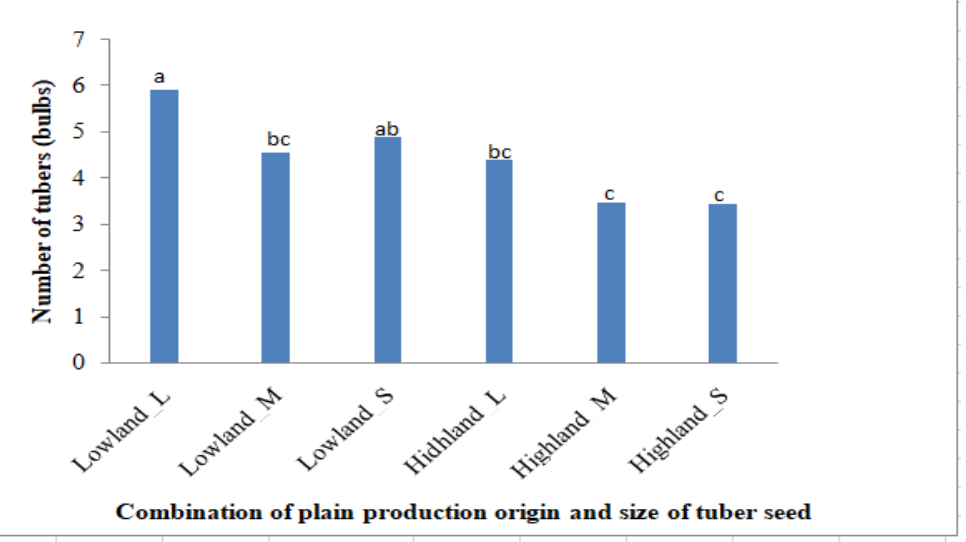

Fig 4: Differences in combination between the origin of potato seed production (lowland and highland) with tuber sizes $(L, M$, and $S$ ) on the number of tubers.

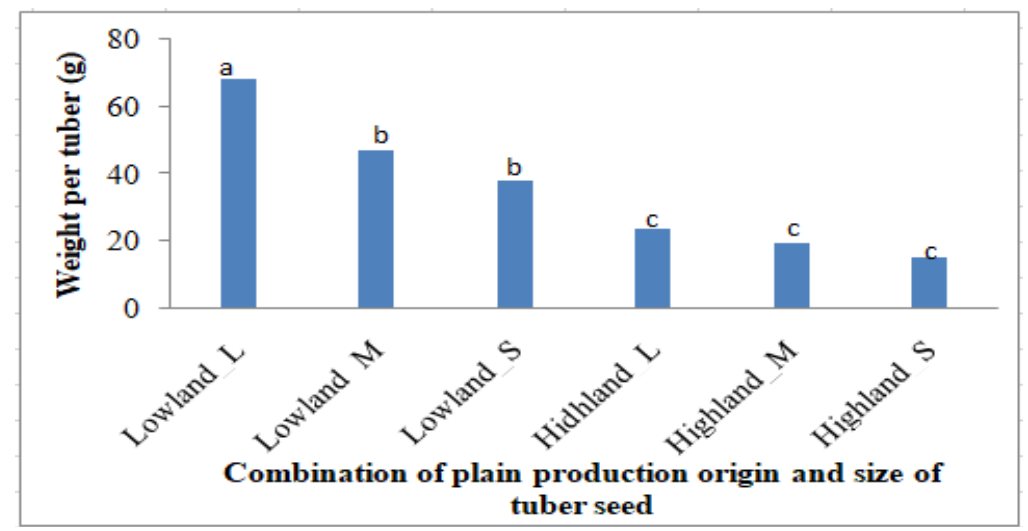

Fig 5: Differences in combination between the origin of potato seed production (lowland and highland) with tuber sizes ( $L, M$ and $S$ ) on the weight per tuber.

The growth of plant height and the number of leaves for L-size seeds have higher growth potential compared to S- and M-size seeds. These results are consistent with a previous study, in which plants from larger seed potato tubers have higher growth potential than smaller seed tubers. The large and the larger potato tubers show greater efficiency in the overall use of metabolites, as measured by growth and yield components at all levels of plant density, compared to small and medium seeds. This has implications for the duration of bulking, physiological growth and effects on the yield obtained at harvest (Masarirambi et al., 2012).

Mini aeroponic seeds of the largest size (L) are presumed to have decreased water content than $\mathrm{M}$ - and Ssize seeds. This allows the L-size seed to maintain robustness longer in order to produce a greater plant height, number of leaves and tuber yield compared to the $M$ and $S$ sizes. These results are similar to results of a previous study, as the larger microtubers have a shorter dormancy time and show stronger growth capabilities. Starch content increases in line with increasing microtuber size, with a distribution of about $70-80 \%$ dry matter content. The amount of sugar is positively related to the size of the potato. Internal factors such as dry matter and carbohydrate content reveal that microtuber potatoes follow potatoes grown in the field in all aspects. The result shows that the size of microtubers can be used as an index to assess their quality as seed potatoes, and the size of the microtubers should be at least $0.5 \mathrm{~g}$ to be used as potato seeds (Park et al., 2009). From the results of this research, we also found that the aeroponic potato seeds produced in the lowland have higher yield potential than potato seeds that are aeroponically planted in the highland. In this research, aeroponic seeds planted with drip irrigation became advanced seeds, as showed in Fig 3.

\section{CONCLUSION}

Seeds of aeroponic yields of various sizes that are planted using drip irrigation have the potential to become advanced seeds. The result of statistical analysis shows that the aeroponic seeds from the lowland (modified root) of the $L$ size have higher potency than aeroponic seeds from the highland. The aeroponic seeds of the $L$ size from the lowland produced an average of 5.9 tubers at an average weight of $68.4 \mathrm{~g}$.

\section{ACKNOWLEDGEMENT}

We thank Kemenristekdikti for the National Strategic Grant funding (no. 2045/UN23.14/PN/2017) that was given in 2017 so this research could be conducted. 
The Effect of Aeroponic Potato Seeds from the Tropical Lowland and Highland Based on Size on the Growth and Yield to...

\section{REFERENCES}

Ahmadvand, G., Mondani, F and Golzardi, F. (2009). Effect of crop plant density on critical period of weed competition in potato. Scientia Horticulturae. 121: 249-254.

Bentley, J and Vasques, D. (1998). The Seed Potato System in Bolivia: Organizational Growth and Missing Links. Network Paper No. 85. London, England: Overseas Development International (ODI). $11 \mathrm{p}$.

[FAO] Food and Agriculture Organization. (2007). Food and Agricultural Commodities Production. http://faostat.fao.org/ site/339/default.aspx [08 August 2011].

Farran, I. and Castel, M. (2006). Potato minituber production using aeroponics: Effect of plant density and harvesting intervals. American Journal Potato Research. 83: 47-53.

Karim, M.R., Hanif, M.M., Shahidullah, S.M., Rahman, M.A., Akanda, A.M. and Khair, A. (2010). Virus free seed potato production through sprout cutting technique under net-house. African Journal Biotechnology. 9: 5852-5858.

Malik, K., Kumar, P. and Kumar, M. (2018). Potato seed crop will be affected more by vectors under changing climatic conditions. Indian J. Agric. Res. 33(3): 173-176.

Masarirambi, M.T., Mandisodza, F.C., Mashingaidze, A.B. and Bhebhe, E. (2012). Influence of plant population and seed tuber size on growth and yield components of potato (Solanum tuberosum). International Journal of Agriculture and Biology. ISSN Print: 1560-8530; ISSN Online: 18149596.

Mhatre, P.H., Divya, K.L., Venkatasalam, E.P., Bairwa, A., Sudha, $\mathrm{R}$ and Berliner, J. (2019). Potato cyst nematode: A hidden enemy of potato cultivation in hills. Bhartiya Krishi Anusandhan Patrika. 34(1): 50-53.

Otazu, V. (2010). Manual on Quality Seed Potato Production Using Aeroponics. Lima, Peru: International Potato Center (CIP)

Park, S. W., Jeon, J.H., Kim, H.S., Hong, S.J., Swath, C. and Joung, H. (2009). The effect of size and quality of potato microtubers on quality of seed potatoes in the cultivar 'Superior'. Scientia Horticulturae. 120: 127-129.

Priyank, H.M., Divya, K.L., Venkatasalam, E.P., Bairwa, A., Sudha, R. and Berliner, J. (2019). Potato cyst nematode: A hidden enemy of potato cultivation in hills. Indian J. Agric. Res. 34(1): $50-53$.
Rana, R.K., Sharma, N., Arya, S. Kadian, M.S. and Singh, B.P. (2013). Seed potato utilization pattern and its impact on farmers profitability in Karnataka. Indian J. Agric. Res. 47(6): 488-495.

Rykaczewska, K. (1993). Effect of temperature during growing season and physiological age of minitubers on potato plant development and yield. Bulletin of the Potato Instatute. 42(1): 39-46.

Rykaczewska, K. (2013). The impact of high temperature during growing season on potato cultivars with different response to environmental stresses. American Journal of Plant Sciences. 4: 2386-2393.

Sumarni, E. (2013). Pengembangan zone cooling system untuk produksi benih kentang secara aeroponik di dataran rendah tropika basah. Disertasi, Institut Pertanian Bogor. IPB. Bogor.

Sumarni, E., Ardiansyah and Sumartono, G.H. (2011). Pengembangan produksi benih kentang di sentra Banjarnegara. Laporan Riset Unggulan Daerah. Kerjasama Unsoed-Balai Penelitian dan Pengembangan Propinsi Jawa Tengah.

Sumarni, E., Herry, S., Kudang, B.S and Saptomo, S.K. (2013a). Aplikasi pendinginan zona perakaran (root zone cooling) pada produksi benih kentang menggunakan sistem aeroponik. Journal Agronomy Indonesia. 41: 154-159.

Sumarni, E., Herry, S., Kudang, B.S. and Saptomo, S.K. (2013b). Perpindahan panas pada aeroponik chamber dengan aplikasi zone cooling. Jurnal Biofisika. 9: 8-19.

Sumarni, E., Herry, S., Kudang, B.S and Saptomo, S.K. (2013c). Seed potato production using aeroponics system with zone cooling in wet tropocal lowlands. Proceeding. Second Asia Pacific Symp. on Postharvest Research, Education and Extension. Eds. Acta Hort. 1011. ISHS.

Sumarni, E., Noor, F., Loekas, S., Darjanto and Ardiansyah (2019). Effect of Electrical Conductivity (EC) in the Nutrition Solution on Aeroponic Potato Seed Production with Root Zone Cooling Application in Tropical Lowland, Indonesia. Agricultural Engineering International: CIGR Journal 21(2): 70-77. Open access, http://www.cigrjournal.org.

Tedy, S., Endjang, S. and Taemi, F. (2011). Peluang usaha penangkaran bibit kentang di Jawa Barat. Buletin Hasil Kajian 1(1): 1-4.

Van Dam, J., Kooman, P.L. and Struik, P.C. (1996). Effects of temperature and photoperiod on early growth and final number of tubers in potato (Solanum tuberosum L.). Potato Research. 39(1): 51-62. http://dx.doi.org/10.1007/ BF02358206. 